\title{
Development of PIAUD Science Learning Media (PSLM) Based on Wonosobo Local Wisdom
}

\author{
Nugroho Prasetya Adi ${ }^{1, *}$ Vava Imam Agus Faisal ${ }^{2}$ \\ ${ }^{1}$ Department of Physics Education, Tarbiyah and Teacher Training Faculty, Al-Qur'an Science University \\ ${ }^{2}$ Early Chilhood Islamic Education, Tarbiyah and Teacher Training Faculty, Al-Qur'an Science University \\ *Corresponding author. Email: nugrohoprasetyaadi@gmail.com
}

\begin{abstract}
The entry of foreign cultures through various things caused the fading of the knowledge of Indonesia's young generation toward their own culture. The introduction of culture from an early age should be encouraged to overcome these problems. One of them through education, where students are introduced to their culture's through the learning proces. PIAUD Science Learning Media (PSLM) is a learning media was developed for early chilhood education level. PSLM was developed with science concept to introduce surrounding nature. In other, PSLM was developed based on cultures of Wonosobo local wisdom, the purpose is to introduce wonosobo cultures to student from an early age. The aim of this research are develop PIAUD Science Learning Media (PSLM) and determine the feasibility of media and science material from PIAUD Science Learning Media (PSLM) based on assessment of expert and practitioners. The research method was used is Research and Development (R\&D), which the product was developed is PSLM. Instrument used in this research were media and science material validation sheets, media and material science feasibility sheets by expert and practitioners. The result showed that feasibility assessment instrument of media and science material has valid and reliable based on expert assessment and has produced PSLM was feasible in media and science material with very good category based on expert assessment.
\end{abstract}

Keywords: PIAUD science learning media, Wonosobo local wisdom

\section{INTRODUCTION}

The learning process at early chilhood level emphasizes games, skill, intuition, and improve information for the growth and development of his knowlegde. Earcly chilhood education is aimed to children aged 0-6 years, where this education is given to help children in adaptation process before entering his formal education at the primary level. At 0-7 years is golden age in the development of children thinking, which according Piaget's theory that the children at this age is on the pre-operation stage. Intelectual abbilities of children are formed at 4-7 years, reaching $80 \%$ at the 8 years. In range $4-6$ years, the absorption of children information is very high, therefore at this age children are advised to be given knowlegde and skill [1]. The process of education and learning in early chilhood must be carried out to provide meaning and concept through the real experiences [2]. At this stage, the children tryies to understand symbol and intuitif concept. So that giving knowlegde concept and skill to children at an early age is highly recommended [3]. The role of the teacher in learning process at early chilhood is crutial for the growth and development of a children thinking. One of the factor that affect learning quality is how a teacher is able to bring student into what they are learning [4]. Therefore, using tools to facilitate teachers in learning process at early chillhood level is the use appropriate learning media.

The learning process at the class has 5 elements of communication, namely teachers, teaching material, learning media, students, and learning objectives. Learning media is one of the main elements that must be used by a teacher in delivering learning material to students. The important role of learning media in teaching and learning process indicates that teacher must be able to process the media as well as possible, so that learning becomes more interested and efficient. The use of learning media is a way of the teacher to use teaching tools as an intermediary in the learning process to facilitate the achievement of teaching goals [5]. Learning media is one of facilities to transmit or sending message and in the learning perspective is to 
deliver material content to students to achieve effective instruction $[6,7]$.

The use of learning media must be serious concern from teacher to facillitate every process of learning and teaching [8]. The accuracy of the teacher to choose learning media will greatly impact at learning process, especially the learning process in early chillhood. Where the children at an early age (0-6 years), need more information, skill, and stimulation [3]. So, the used of learning media for chillhood age will be help a student to improve his knowlegde and skills. In other, the use learning media at early chillhood makes it very easly for teacher to instill the concept that will be given.

The research result shows that the use learning media for earky chillhood be can stimulate children to be more active and able to connect for one situation to other situation, and can improve his knowledge [9, 10, 11]. The use learning media is an application of industrial revolution 4.0, where this era is known as disruptibe innovation, there are 3 important element that must be include, namely information literacy, media literacy, and ICT literacy [12].

The development of technology in recent years has had positive and negative impact in several areas of life. One of the positive impact of technological progress is too fast spread of Indonesian and world culture that can be accessed via electronic tools. This cultural distribution indirectly provide knowlegde for Indonesian young generation about cultures from the other countries, so be able to increase their knowlegde. In other side, the cultures distribution has had negative impact for preservation of Indonesian indigenous cultures. One of negative impact from cultures distribution is entering the foreign culture that are able to fade the origin Indonesian cultures. This situation raises concern, because Indonesia is facing the erotion of the values of local wisdom which are slowly being forgotten by its own population, especially Indonesian young generation [13]. The research result show that Indonesia is experiencing a cultural crisis, where expantion of foreign cultures be able change the mindset and action of society which can loss of humanity value, religion, and cultures [14]. One of the steps that can be taken to overcome the fading of Indonesian cultures is to introduce Indonesian origin culturesto the younger generation from an early age through education. The introduction of culture from an early age can have an important impact on the growth of love for Indonesian origin cultures, considering that the stages of growth in the mind of early chilhood are a golden age period in human motoric development.

Introduction of Indonesian cultures through education can be given either through science learning, where science is a subject that is closely related to the environment. This learning is suitable to be taught to early chillhood, because it is able to teach about loving the environment, and sensitive to the environment. In other hand, science learning are also able to hone children's motoric through small experience that can be given to children and increase gratitude to the Creator. Trunder states that science learning at early chillhood education provides biggest benefits for various aspects of children development [15]. Gross explained that science learning is a process of conceptual changes which the children rearrange the knowlegde they already have to understands concept and process more completely [16]. Indirectly, the impact of study science is increase religius character, loving environment, carring attitude, and responsibility. This is in line with the goverment of Indonesia's program, where character education must be emphasized at the school level. In reality, science learning rearly associated with local wisdom values inhereted from anchestor, eventhough science is closely related to the environment and cultures. Therefore, we need a liaison that is able to integrate these two things into learning process, one of which is by utilizing learning media based on local wisdom.

The purposes of the research is development PIAUD Science Learning Media (PSLM), determine the feasibility of media and the feasibility of material from PIAUD Science Learning Media (PSLM) based on expert judgment.

\section{RESEARCH METHOD}

\subsection{Types of Research}

This research used Research and Development (R\&D) method. R\&D is a research method which will produce certain product [17]. The product being developed is PIAUD Science Learning Media Based on Wonosobo Local Wisdom for early chilhood education. The development model used is Borg \& Gall, where according this model there is 9 stages that must be implemented

\subsection{Subject}

The research subjects are teachers who teach at the PAUD level spread across Wonosobo regency. The subject were 32 teachers who come from PAUD/PIAUD at Wonosobo regency.

\subsection{Technique of Data Collection}

The instrument used in this research included: media validation sheets, material validation sheets, media feasibility sheets, and material feasibility sheets by an expert. The research data collected is validation 
of media instruments and validationof material instruments generated from validation sheets. Teachers assessment data about PSLM is related to media and material assessment using feasiblity sheets.

\subsection{Technique of Data Analysis}

\subsubsection{Instrument Validity of Media and Science Material}

Content validity is determined using expert agreement. Expert agreement is measured by determining the validity level of instruments content, using the validity index by Aiken.

\subsubsection{Feasibility Analysis of Media and Science Material}

The science material sheets analyzed using a modified Linkert scale. The technique used to analyze feasibility data is carried out in the following steps:

a. Tabulate all the data obtained

b. Calculate the average score of each component

c. Converting the average score into a value.

d. Data from suggestion and comments were analyzed descriptive qualitative.

To determine the quality of media and science material feasibility, the data was converted from scores to qualitative data (interval data) using linkert scale. The reference for changing the scores to 4 scale can be seen on Table 1

Table 1. The reference for changing the scores to 4 scale

\begin{tabular}{|c|l|c|c|}
\hline No & \multicolumn{1}{|c|}{ Score Range } & Value & Category \\
\hline 1 & $x>\bar{X}+1 S B_{x}$ & A & Very Good \\
\hline 2 & $\bar{X}+1 S B_{x}>X \geq \bar{X}$ & B & Good \\
\hline 3 & $\bar{X}>X \geq \bar{X}-1 S B_{x}$ & C & Enough \\
\hline 4 & $x<\bar{X}-1 S B_{x}$ & D & Not Good \\
\hline
\end{tabular}

Based on Table 1, a scale of 4 conversion can be carried out in Table 2

Table 2. Result of converting score to 4 scale

\begin{tabular}{|c|l|c|c|}
\hline No & \multicolumn{1}{|c|}{ Score Range } & Value & Category \\
\hline 1 & $x \geq 3,00$ & A & Very Good \\
\hline 2 & $3,00>x \geq 2,51$ & B & Good \\
\hline 3 & $2,51>x \geq 2,01$ & C & Enough \\
\hline 4 & $x<2,00$ & D & Not Good \\
\hline
\end{tabular}

The value of media and science material in this research is in the "Enough" category or with $\mathrm{C}$ a value

\section{RESULT AND DISCUSS}

\subsection{PIAUD Science Learning Media (PSLM) Based On Wonosobo Local Wisdom}

The words media come from plural word medium come from latin language medius, which means intermediary. Media is often used by many people in everyday life, including in the teaching and learning in school. Media in the learning process tends to be intepreted as a graphic, fotographic tool for lifting, processing, and rearranging received visual or verbal information [18, 19]. Learning media can be used as an alternative source in the learning process that takes place if it well disigned, so that help student digest and understand leaning material [20,21]. Interesting learning media are also able to stimulate students attention so that the material presented by teachers will be well understood by students [22].

PIAUD Science Learning Media is learning media disigned with the science concept for early chillhood. This learning media was developed to introduce early chilldhood about science concept, so as to form the character of children who lovethe environtment and has gratitude to Creator, and has concern to other. PIAUD Science Learning Media was developed according to the level of thingking PAUD children where playing is interesting learning process for them. Learning process in early chillhood must be harmony with the child's development, eduction programs must be adapted to the child, not children who must adapt to the program [23]. PIAUD Science Learning Media was developed to close with children environment, so that the concept in the media can make it easier for children to understand.for children to understand.

PIAUD Science Learning Media was developed based on local wisdom in Wonosobo regency, the aim is to make easier for students to undertands science material and to introduce wonosobo cultures to students. Local wisdom is part of cultures that develops in an areas. Javanese local wisdom for example, is of course part of javanese cultures [24]. The use of local wisdom aims to introduce children to the origin cultures of their areas, which has recently been forgotten due to the influence of other cultures that have entering to Indonesia. Local wisdom is knowlegde source that is dynamic, develops, and influence certain communities, and integrated with the surrounding nature and their origin cultures [25, 26]. Local wisdom that is studied with science can foster knowlegde in students [25]. In Indonesia, local wisdom is philosophy and a view of life that is embodied in several aspects of life such as socio- 
economy value, arsitecture, health, environment management etc [27].

Based on definition of local wisdom, it can be concludethat local wisdom able integraated with science leaning which emphazing in local wisdom of Central Java, especially Wonosobo.

\subsection{Validity of Media and Science Material Instrument}

Validity of instrument is carried out to knowing that instrument will used in assesing product is valid and reliable. The purpose of this validation is so that instrument used can measure what should be measured.
Before instrument used to evaluate the product is validated first to determine the validityof the instrument. The instrument that was validated is data collection instrument consisting of a media feasibility sheets and science material for PSLM based on Wonosobo local wisdom. Instrument was developed by Forum Group Discussion (FGD) before being submitted to expert for validation. Instrumen validation is carried out by 3 expert lectures who has background early chillhood education. The result of the instrument validation by experts are presented in Table 3. Instrument reability was obtained from the analysis process after the instrument was used directly by 5 assesors, so that the data analyzed was the result of product assesment.

Table 3. The result of instrumen validity and reability

\begin{tabular}{|c|l|c|c|c|}
\hline No & \multicolumn{1}{|c|}{ Instrumen } & Validity Coef $(\boldsymbol{N})$ & Intepretasi & Reliabilitas \\
\hline 1 & Media feasibility sheets & 1,00 & Valid & \multirow{2}{*}{ Reliable } \\
\hline 2 & Science material feasibility sheets & 1,00 & Valid & \\
\hline
\end{tabular}

Based on Table 3, instrument was developed have been valid and reliable based on expert lectures jugdment, so that instrument can be used to assess the feasibility of media and science material.

\subsection{The Result of Feasibility Assesment}

\subsubsection{Media Feasibility}

This stage has purpose to knowing media feasibility of PSLM based on Wonosobo Local Wisdom. The data was generated at this stage are in the form qualitative and quantitative data derived from assessment and input from teacher. The quantitative data was generated at this stage are in the form of score given by practitioners (teachers) to the PSLM based on Wonosobo local wisdom and qualitative data was generated is category from quantitative data and input from practitioners to PSLM based on Wonosobo local wisdom. Media feasiblity assessment of PSLM based Wonosobo local wisdom is carried out by 32 practitioners, who come from 32 school at the PAUD level spread throughout Wonosobo regency. Selection of experts to assess media feasibility is done randomly to obtain appropriate data.

The result of media feasibility assess by practitioners showed in Table 4

Table 4. The result of media feasibility assessment

\begin{tabular}{|c|l|c|c|}
\hline No & \multicolumn{1}{|c|}{ Aspect } & Average score & category \\
\hline 1 & Suit the use of the colour with the background & 3.59 & Very Good \\
\hline 2 & Suit the use of the letters with media & 3.56 & Very Good \\
\hline 3 & Suit the use of fonts and legibility on media & 3.53 & Very Good \\
\hline 4 & Suit the media with PAUD/PIAUD level (6 Years) & 3.59 & Very Good \\
\hline 5 & Suit the colour background with writing & 3.78 & Very Good \\
\hline 6 & Ease of operating the media as a learning media & 3.53 & Very Good \\
\hline 7 & $\begin{array}{l}\text { Suit the picture with science concept PAUD/PIAUD } \\
\text { level (6 Years) }\end{array}$ & 3.59 & Very Good \\
\hline 8 & Attractiveness image provided & 3.53 & Very Good \\
\hline 9 & Picture has element of wonosobo local wisdom & 3.66 & Very Good \\
\hline
\end{tabular}




\begin{tabular}{|c|l|c|c|}
\hline No & \multicolumn{1}{|c|}{ Aspect } & Average score & category \\
\hline 10 & $\begin{array}{l}\text { Pictures according to the environment around } \\
\text { students }\end{array}$ & 3.53 & Very Good \\
\hline Average score & 3.59 & Very Good \\
\hline
\end{tabular}

Based on Table 4, it is obtained average scores 3.59 with category Very Good. So that based on media feasiblity assess by practitioners of PSLM based Wonosobo local wisdom, it can be conclude that the learning media PSLM based Wonosobo local wisdom is very suitable for use in learning process at PAUD/PIAUD levels.

In addition to providing feasibility assessment of media at PSLM based on Wonosobo local wisdom, practitioners also provide suggestion for improving PSLM before it is disseminated, namely the combination of colour fonts and background, and the use of fonts on the PSLM based Wonosobo local wisdom.

\subsubsection{Science Material Feasibility}

This stage has purpose to knowing science material feasibility on the PSLM based Wonosobo local wisdom. The data was generated in this stage are in the form quanitative and qualitative data. Quantitative data was generated in this stage are in the form of scores given by practitioners (teacher) and qualitative data was generated is category from quantitative data.

Content and construct assessment from science material on the PSLM based Wonosobo local wisdom is carried out by teacher who come from 32 scholl in early chillhood education level that spread in Wonosobo regency Central Java. Aspect that are assess by practioners are science material aspect that are adjust to the level of development of children at an early age. The result of feasibility assess of science material by practitioners is showed in Table 5 .

Table 5. The result of science material feasibility

\begin{tabular}{|c|l|c|c|}
\hline No & \multicolumn{1}{|c|}{ Aspect } & \multicolumn{1}{|c|}{ Average Score } & Category \\
\hline 1. & Suit of science material with PAUD/PIAUD level & 3.63 & Very Good \\
\hline 2. & Clarity of the material presented & 3.34 & Very Good \\
\hline 3. & The existence of science elements & 3.50 & Very Good \\
\hline 4. & The truth of science element & 3.56 & Very Good \\
\hline 5. & The material presented contains elements of wonosobo local wisdom & 3.75 & Very Good \\
\hline 6. & The suit of wonosobo local wisdom with science material & 3.44 & Very Good \\
\hline 7. & Use of language according to the level of development of students & 3.31 & Very Good \\
\hline 8. & Grammatical accuracy & 3.38 & Very Good \\
\hline 9. & Suit of language with message substantion & 3.56 & Very Good \\
\hline 10. & The language used is able to convey the message to students & 3.63 & Very Good \\
\hline Average score & 3.51 & Very Good \\
\hline
\end{tabular}

Based on the result of practitioners assessment to science material feasibility in PSLM based Wonosobo local wisdom that developed, has obtained average scores 3.51 with Very Good category, so can be conclude that science material in PSLM based Wonosobo local wisdom is very suitable to use for learning process at early childhood education level.

In addition to providing feasibility assessment of science material at PSLM based on Wonosobo local wisdom, practitioners also provide last conclusion from their assessment. Practitioners given conclusion that science material was developed on the PSLM based Wonosobo local wisdom is suitable to taught in early childhood education levels with revision, that is more attention to writing system, colours collaboration was used to repair 


\section{CONCLUSION}

The conclusion of this research that is

a. The research was conducted has resulted PIAUD Science Learning Media (PSLM) based on Wonosobo local wisdom product.

b. Research instrument has met the valid and reliable criteria

c. Media was developed in PIAUD Science Learning Media (PSLM) based Wonosobo local wisdom has met feasibility criteria of media and science material with very good category based on assessment of 32 practitioners who have early childhood education background that come from 32 school of PAUD/PIAUD levels spread in Wonosobo regency.

\section{ANKNOWLEDGMENT}

This research was conducted through a beginner lecturer research grant program (PDP) provided through Higher Education (DIKTI) Ministry of Education and Culture (KEMDIKBUD). Therefore, the researchers would like to thank to the parties involved in the Ministry and Research Institute, Publishing, and Community Service (LP3M) Al-Qur'an Science University, so that authors can submit a proposal and get this research grant.

\section{REFERENCES}

[1] R. Naili, W, Edi, Artihmetic Dice Media as Counting Concept Introduction Media in Early Chilhood Setting. Indonesian Journal of Early Childhood Education Studies 3(2) (2014).

[2] A. Taufik,. et al. Parental Perspective on the Excellence of Computer Learning Media in Early Childhood Education. Jurnal Pendidikan Usia Dini 132 (2019). DOI: https://doi.org/10.21009/JPUD.132.11. 356-370.

[3] J. Tusifa, T. Neneng, Bead Board Letter Effectiveness for the Introduction of Reading Concept Among Children Aged 5-6, Indonesian Journal of Early Childhood Education Studies 4(1) (2015) 46-50.

[4] J. Andriessen, Arguing to learn. In R. K. Sawyer (Ed.), The Cambridge Handbook Of The Learning Argumentive Discourse, Discourse Processes 48 (2006) 26-49.

[5] N.P. Adi, K. Yohannes, Meningkatkan Higher Order Thinking Skill Dan Sikap Terbuka Melalui Media Pembelajaran Android, Journal of Komodo 1(1) (2018) 79-94.

[6] A.N. Ahsan, A.A. Rafaqat, Use of Media for Effective Instruction its Importance: Some
Consideration, Journal of Elementary Education 18 (2018) 35-40.

[7] D.Y. Saputri, et al. Integrating Game-based Interactive Media as Instructional Media: Students Response. Journal of Education and Learning, Vol 14(8) (2018) 638-643.

[8] A. Yohana, The Study of Learning Media Used in the Subjects of Cultural Arts in the Fine Arts Sector at Junior High School Probolinggo, S.Pd thesis, Universitas Negeri Malang, Malang, 2011

[9] E. Hendarwati, Pemanfaatan Media Dalam Pembelajaran Pengetahuan Sosial Di Taman KanakKanak. Jurnal Pendagogi 1 (2014) 1-7

[10] N. Saurina, Pengembangan Media Pembelajaran Untuk Anak Usia Dini Menggunakan Augmented Reality, Jurnal IPTEK 20 (2016) 95-108.

[11] S. Shoffa, Penerapan Media Puzzle Cerdas Untuk Meningkatkan Kemampuan Kognitif Anak Taman Kanak-Kanak Dalam Berhitung, Jurnal Pedagogi 1(1) (2014) 8-16.

[12] N. Rohmah, E. Waluyo, Arithmetic Dice Media as Counting Concept Introduction for Early Childhood. Indonesian Journal Of Early Childhood Education Studies (2014) 3(2) (2014) 127-133.

[13] Binkley, M., et al. Defining Twenty-First Century Skills, Assessment and Teaching of 21st Century Skills (2012) 12-19.

[14] A.S. Mubah, Strategi Meningkatkan Daya Tahan Budaya Lokal dalam Menghadapi Arus Globalisasi. Departemen Hubungan Internasional 24(4) (2011) 302-308

[15] I.W. Suastra, P.B.Y. Luh, Model Pembelajaran Fisika Untuk Mengembangkan Kreativitas Berpikir dan Karakter Bangsa Berbasis Kearifan Lokal Bali. Jurnal Pendidikan Indonesia 20(2) (2013) 2303-288

[16] Widodo, Johannes, Urban Environment and Human Behaviour: Learning from History and Local Wisdom, in: Procedia - Social and Behavioral Sciences, vol. 42, IOP Publishing, Bristol, 2012, 6 11.

[17] Sugiyono, Research method, Alfabeta, 2015

[18] Mungmachon, Roikhwanphut, Knowledge and Local Wisdom: Community Treasure, International Journal of Humanities and Social Science, 2, (2012) 174-181.

[19] Mirawati, N. Rini, Meningkatkan Keterampilan Proses Sains Anak Usia Dini Melalui Aktivitas Berkebun. Early Childhood: Jurnal Pendidikan, 1(1) (2017) 1-15. 
[20] C.M. Gross, Science Concepts Young Children Learn Through Water Play. Dimensions of Early Childhood 20(2) (2012)

[21] A. Arsyad, Learning Media, PT Raja Grafindo Persada, 2014.

[22] Daryanto, Learning Media, Gava Media, 2010.

[23] A. Hasjiandito, et al., Presenting Religious Topics: The Effectiveness of Microsoft Powerpoint. Indonesian Journal of Early Childhood Education Studies 4(2) (2015) 111-115.

[24] Wagiran, Pengembangan Model Pendidikan Kearifan Lokal dalam Mendukung Visi Pembangunan Provinsi Daerah Istimewa
Yogyakarta 2020, Jurnal Penelitian dan Pengembangan 3 (2011) 85-100.

[25] Kanhadilok, Peeranut, Watts, Mike, Western Science and Local Thai Wisdom: Using Museum Toys to Develop Bi-Gnosis, Canadian Journal of Science, Mathematics and Technology Education, 13(1) (2013) 33-48,

[26] Demaio, Alessandro, Local Wisdom and Health Promotion: Barrier or Catalyst?. Asia-Pacific Journal of Public Health, 232 (2011) 127-132,

[27] Ministry of Education and Culture, Analysis of Local Wisdom in terms of Cultural Diversit, PDSPK, 2016. 